\title{
PENGARUH PENGGUNAAN ANTIANEMIA TERHADAP KADAR HEMOGLOBIN PASIEN GAGAL GINJAL KRONIK
}

\author{
(ANTIANEMIA ROLE TOWARDS HEMOGLOBIN VALUE \\ IN PATIENTS WITH CHRONIC KIDNEY DISEASE)
}

\author{
HERLEEYANA MERIYANI*•, NI KADEK AYU SARTIKAWATI*, I MADE AGUS SUNADI PUTRA* \\ ${ }^{*}$ Farmasi Fakultas Farmasi Universitas Mahasaraswati Denpasar, Jalan Kamboja No. 11A Denpasar Bali
}

\begin{abstract}
Abstrak: Anemia merupakan salah satu masalah kesehatan yang sering ditemukan pada pasien gagal ginjal kronis. Pemeriksaan hemogloblin rutin sangat disarankan pada pasien gagal ginjal kronis dengan anemia. Adapun tujuan dari penelitian ini adalah untuk mengetahui pengaruh penggunaan antianemia terhadap peningkatan kadar hemoglobin pada pasien gangguan ginjal kronis dengan komplikasi anemia. Penelitian ini merupakan penelitian non-eksperimental dengan rancangan cross sectional. Pengambilan data dilakukan secara retrospektif dengan menggunakan data rekam medis di RSUD Wangaya periode 2018. Untuk melihat pengaruh penggunaan antianemia dilakukan dengan membandingkan hemoglobin sebelum dengan sesudah terapi. Pasien gagal ginjal kronis yang menjadi subjek dalam penelitian ini yaitu berjumlah 64 orang. Sampel terdiri atas $64 \%$ laki laki dan $36 \%$ perempuan. Berdasarkan profil penggunaan obat antianemia, sebanyak 95, $29 \%$ menggunakan obat asam folat; $1,57 \%$ menggunakan kombinasi eritropoetin-Fe sucrose-asam folat; sebanyak 1,57\% menggunakan eritropoetin-asam folat; dan 1,57\% menggunakan ferrous sulfat-asam folat. Dari hasil penelitian yang telah dilakukan, bahwa penggunaan antianemia pada pasien gagal ginjal kronik di Rumah Sakit Umum Daerah Wangaya periode 2018 dapat meningkatkan kadar hemoglobin pasien gagal ginjal kronis $(\mathrm{p}<0.05)$. dari penelitian ini dapat disimpulkan bahwa penggunaan antianemia telah efektif dalam meningkatkan kadar hemoglobin pasien dengan gagal ginjal kronis.
\end{abstract}

Kata Kunci: gagal ginjal kronik, terapi antianemia

\begin{abstract}
Anemia is one of health problem in patients with chronic kidney disease. Hemoglobin value is one of health parameter routine examination. The aimed of this study was to determine the effectiveness of antianemia therapy towards hemoglobin value in patients with chronic kidney disease. This study was nonexperimental study with cross sectional study design. Data collection was done retrospectively in RSUD Wangaya 2018. To assess the influence of anti-anemia was done by comparing hemoglobin value before and after therapy. Sample sizes in this study were 64 patients with chronic kidney disease consist of $64 \%$ male and $36 \%$ female. Based on drug use profile, there are $95.29 \%$ use folic acid; $1,57 \%$ use erythropoietin-Fe Sucrosefolic acid combination; $1,57 \%$ use erythropoietin-folic acid combination; and 1,57\% use Fe sucrose-folic acid combination. Based on statistical analysis, the use of anti-anemia affects the level of hemoglobin $(\mathrm{p}<0.05)$. We conclude that the use of anti-anemia therapy is effective improve level of hemoglobin in patient with chronic kidney disease.
\end{abstract}

Keywords: chronic kidney disease, anti-anemia therapy

\section{PENDAHULUAN}

Gagal ginjal kronik (GGK) adalah masalah utama kesehatan di masyarakat yang merupakan perkembangan penyakit yang lama dan progresif serta memiliki etiologi yang beragam (Pusat Data dan Infomasi Kementerian Kesehatan RI, 2017).

Prevalensi gangguan ginjal kronis meningkat seiring dengan bertambahnya umur, meningkat drastis pada umur 35-44 tahun $0,3 \%$, diikuti rentang umur 45-54 tahun 0,4\%, dan umur
55-74 tahun $0,5 \%$, paling tinggi pada kelompok umur $\geq 75$ tahun $0,6 \%$. Prevalensi pada laki-laki menunjukkan angka 0,3\% lebih tinggi dari perempuan yaitu $0,2 \%$ (Badan Penelitian dan Pengembangan Kesehatan Kementerian Kesehatan RI, 2013). Gagal ginjal kronik merupakan penyebab kematian peringkat ke-27 di dunia tahun 1990 dan meningkat menjadi urutan ke-18 pada tahun 2010 (Pusat Data dan Infomasi Kementerian Kesehatan RI, 2017). Penyakit gagal ginjal kronik

\footnotetext{
• e-mail korespondensi: ching25.lee@gmail.com
} 
di provinsi Bali tahun 2009 ada sebanyak 71 kasus rawat inap, tahun 2010 sebanyak 643 kasus rawat inap dan tahun 2011 sebanyak 904 kasus (Dinas Kesehatan Provinsi Bali, 2010).

Anemia terjadi pada $80-90 \%$ pasien penyakit ginjal kronik. Anemia pada penyakit ginjal kronik terutama disebabkan oleh defisiensi eritropoetin, hal lain yang dapat berperan dalam terjadinya anemia pada pasien gagal ginjal kronik adalah defisiensi Fe, kehilangan darah, masa hidup eritrosit yang memendek, defisiensi asam folat, serta proses inflamasi akut dan kronik.

Anemia dengan konsentrasi hemoglobin $<13,0 \mathrm{~g} / \mathrm{dl}$ pada laki-laki dan $<12,0 \mathrm{~g} / \mathrm{dl}$ pada wanita (KDOQI, 2012; Cases, 2018). Untuk penatalaksanaan anemia pada pasien gagal ginjal kronik batas bawah hemoglobin normal adalah $11,5 \mathrm{~g} / \mathrm{dl}$ pada wanita dan $13,5 \mathrm{~g} / \mathrm{dl}$ pada laki-laki $\leq 70$ tahun dan $12,0 \mathrm{~g} / \mathrm{dl}$ pada laki-laki $>70$ tahun (The European Best Practice Guidelines, 2002). Anemia pada pasien penyakit ginjal kronik jika kadar hemoglobin <11,0 g/dl (hematokrit <33\%) pada wanita premonopause dan pasien prepubertas, dan $<12,0 \mathrm{~g} / \mathrm{dl}$ (hematokrit $<37 \%$ ) pada laki-laki dewasa dan wanita postmeopause (KDOQI, 2006). Sedangkan dikatakan anemia pada penyakit ginjal jika $\mathrm{Hb} \leq 10 \mathrm{~g} / \mathrm{dl}$ (hematokrit <30\%) (Lubis dan Siregar, 2011).

Pemeriksaan hemoglobin harus dilakukan secara rutin pada pasien dengan GGK. Pada pasien GGK tanpa anemia disarankan:

1. Paling tidak pemeriksaan $\mathrm{Hb}$ setiap tahun pada pasien GGK stage 3

2. Paling tidak dua kali pertahun untuk GGK grade 4 dan 5 tanpa hemodialysis

3. Pada CKD stage 5 paling tidak setiap 3 bulan

Pemeriksaan HB rutin pada pasien GGK dengan anemia disarankan setiap 3 bulan pada pasien GGK stage 3-5 non dialysis dan diserankan setiap bulan pada pasien GGK stage 5 dengan hemodialysis (KDIGO, 2012; Case et al, 2018).

Berbagai obat digunakan dalam penatalaksanaan anemia pada gagal ginjal kronik adalah asam folat, eritropoetin, vitamin B12, Erythropoiesis stimulating agent (ESA), dan zat besi (Ineck et al., 2008; KDIGO, 2012). Penggunaan asam folat memberikan pengaruh kepada pasien gagal ginjal kronik karena dapat meningkatkan kadar hemoglobin pasien dan dalam pembentukan sel darah merah, menstimulasi produk sel darah merah, sel darah putih dan platelet pada anemia megaloblastik Alvionita (2016). Eritropoetin bekerja pada suatu glikoprotein hormon yang akan terikat pada reseptor spesifik progenitor sel darah merah yang selanjutnya memberi sinyal merangsang proliferasi dan diferensasi. Produksi EPO akan meningkat pada keadaan anemia ataupun hipoksia jaringan (Ineck et al., 2008). Vitamin B12 merupakan nutrisi hematopoetik yang bekerja pada proses pembentukan sel darah merah (Bangbola, 2011; Atkinson dan Warady, 2018).

Erythropoesis stimulating agent (ESA) bekerja dengan menstimulasi sumsum tulang untuk mempoduksi sel darah merah. Terapi ini bersifat individual dan digunakan dosis sekecil mungkin sudah cukup menurunkan kebutuhan transfusi darah (Masood, 2012). Zat besi dibutuhkan untuk produksi sel darah merah baru. Zat besi harus disuplai menuju jaringan eritropoetik dalam jumlah cukup (Mikhail et al., 2012). Berdasarkan uraian diatas perlu dilakukan penelitian mengenai peran antianemia dalam meningkatkan hemoglobin pada pasien dengan GGK.

\section{METODE PENELITIAN}

Instrumen Penelitian. Penelitian ini menggunakan data rekam medis di unit rekam medis Rumah Sakit Umum Daerah Kabupaten Wangaya periode 2018.

Rancangan Penelitian. Penelitian ini merupakan penelitian non eksperimental dengan menggunakan rancangan cross sectional. Pengambilan data dilakukan secara retrospektif menggunakan catatan rekam medis. Untuk melihat peran antianemia dilakukan dengan membandingkan kadar hemoglobin pasien GGK sebelum dan sesudah menggunakan antianemia selama 3-6 bulan. Populasi dari penelitian ini adalah pasien rawap inap dengan diagnosa gagal ginjal kronik yang menggunakan terapi antianemia di Rumah Sakit Umum Daerah Wangaya periode 2018. Teknik pengambilan sampel pada penelitian ini menggunakan metode purposive sampling. Sampel yang diambil dari populasi yang sesuai kriteria penelitian.

Kriteria inklusi:

1. Pasien yang menderita penyakit gagal ginjal kronik dengan penyakit komplikasi atau tanpa komplikasi.

2. Pasien yang menderita penyakit gagal ginjal kronik pada usia 20-84 tahun.

Kriteria eksklusi:

1. Pasien gagal ginjal kronik dengan data yang tidak lengkap. 
2. Pasien gagal ginjal kronik dengan data pasien meninggal.

3. Pasien gagal ginjal kronik dengan pulang paksa.

\section{HASIL DAN PEMBAHASAN}

Pasien GGK yang menjadi subjek dalam penelitian ini berjumlah 64 orang. Karakteristik subjek penelitian dapat dilihat pada tabel 1 dan tabel 2

Tabel 1. Karakteristik pasien berdasarkan jenis kelamin

\begin{tabular}{ccc}
\hline $\begin{array}{c}\text { Berdasarkan } \\
\text { Jenis Kelamin }\end{array}$ & Jumlah & Persentase (\%) \\
\hline Laki-laki & 41 & 64,06 \\
\hline Perempuan & 23 & 35,94 \\
\hline Total & $\mathbf{6 4}$ & $\mathbf{1 0 0 , 0 0}$ \\
\hline
\end{tabular}

Pada tabel 1 di atas menunjukan bahwa penderita GGK lebih banyak terjadi pada pasien laki-laki yaitu 64,06\%. Hal ini sesuai penelitian yang dilakukan oleh Idaiani (2011) dimana kejadian gagal ginjal kronik pada laki-laki mempunyai resiko lebih besar mengalami penyakit gagal ginjal dari pada perempuan hal ini disebabkan karena pengaruh perbedaan hormon reproduksi, gaya hidup seperti konsumsi protein, garam, rokok, dan konsumsi alkohol pada pada laki-laki dan perempuan.

Tabel 2. Karakteristik Pasien Berdasarkan Usia

\begin{tabular}{|c|c|c|c|}
\hline Kategori & $\begin{array}{c}\text { Rentang } \\
\text { Usia } \\
\text { (Tahun) }\end{array}$ & Jumlah & $\begin{array}{c}\text { Persentase } \\
(\%)\end{array}$ \\
\hline $\begin{array}{c}\text { Masa remaja } \\
\text { akhir }\end{array}$ & $17-25$ & 3 & 4,68 \\
\hline $\begin{array}{c}\text { Masa dewasa } \\
\text { awal }\end{array}$ & $26-35$ & 1 & 1,57 \\
\hline $\begin{array}{c}\text { Masa dewasa } \\
\text { akhir }\end{array}$ & $36-45$ & 3 & 4,68 \\
\hline $\begin{array}{l}\text { Masa lansia } \\
\text { awal }\end{array}$ & $46-55$ & 20 & 31,25 \\
\hline $\begin{array}{l}\text { Masa lansia } \\
\text { akhir }\end{array}$ & $56-65$ & 24 & 37,50 \\
\hline Masa manula & $\begin{array}{l}\text { Lebih } \\
\text { dari } 65\end{array}$ & 13 & 20,31 \\
\hline \multicolumn{2}{|l|}{ Total } & 64 & 100,00 \\
\hline $\begin{array}{l}\text { Berdasar } \\
\text { ginjal kronik } \\
\text { Wangaya dida } \\
\text { paling banyak }\end{array}$ & $\begin{array}{l}\text { an katag } \\
\text { i Rumah } \\
\text { tkan pasic } \\
\text { itu } 37,50^{\circ}\end{array}$ & $\begin{array}{l}\text { ri usia } \\
\text { Sakit U } \\
\text { n berusia } \\
\text { b. Hal ini }\end{array}$ & $\begin{array}{l}\text { pasien gaga } \\
\text { mum Daeral } \\
56 \text { sampai } 65 \\
\text { sesuai dengai }\end{array}$ \\
\hline
\end{tabular}

Rothenbacher (2008) dimana prevelensi gagal ginjal terbanyak yaitu pada usia lebih dari 64 tahun sebesar $35 \%$. Hal ini disebabkan oleh perubahan fisiologi pada lanjut usia dapat mempengaruhi respon pengobatan. Pada usia lanjut akan mengalami penurunan mekanisme homeostatis sistem kardiovaskular dan sistem saraf pusat serta laju filtrasi glumelurus akan semakin rendah akibat penuaan.

Tabel 3 Gambaran penggunaan antianemia

\begin{tabular}{ccc}
\hline Obat & Jumlah & $\begin{array}{c}\text { Persentase } \\
(\%)\end{array}$ \\
\hline Asam Folat & 61 & 95,31 \\
\hline $\begin{array}{c}\text { Eritropoitin + Fe } \\
\text { Sucrose + Asam Folat }\end{array}$ & 1 & 1,57 \\
\hline $\begin{array}{c}\text { Eritropoitin + Asam } \\
\text { Folat }\end{array}$ & 1 & 1,57 \\
\hline $\begin{array}{c}\text { Ferrous Sulfat (SF) + } \\
\text { Asam Folat }\end{array}$ & 1 & 1,57 \\
\hline Total & $\mathbf{6 4}$ & $\mathbf{1 0 0 , 0 0}$ \\
\hline
\end{tabular}

Berdasarkan penggunaan obat antianemia pada pasien gagal ginjal kronik di Rumah Sakit Umum Daerah Wangaya, obat asam folat lebih banyak digunakan dari pada obat antianemia lainnya. Menurut Alvionita (2016) penggunaan asam folat memberikan pengaruh kepada pasien gagal ginjal kronik karena dapat meningkatkan kadar hemoglobin pasien dan dalam pembentukan sel darah merah, menstimulasi produk sel darah merah, sel darah putih dan platelet pada anemia megaloblastik.

Penggunaan asam folat secara sendiri maupun bersamaan dengan vitamin B6 dan B12 dapat menurunkan kadar dalam plasma homosistein. Penggunaan asam folat sangat diperlukan di dalam usaha pengendalian kadar dalam plasma homosistein pada penderita gagal ginjal ringan sampai gagal ginjal berat. Menurut penelitian oleh Yuliati (2017) bahwa jika kekurangan asupan asam folat dapat mengganggu pematangan sel darah merah muda, yang berakibat pada anemia. Penggunaan asam folat pada pasien GGK juga dapat menghambat progresivitas GGK dan menghambat penurunan eGFR (Xu et al, 2016).

Tabel 4. Gambaran sadium kerusakan ginjal

\begin{tabular}{ccc}
\hline Stadium & Jumlah & Persentase (\%) \\
\hline I & - & 0 \\
\hline II & - & 0 \\
\hline III & 1 & 1,57 \\
\hline IV & 2 & 3,12 \\
\hline V & 61 & 95,31 \\
\hline Total & $\mathbf{6 4}$ & $\mathbf{1 0 0 , 0 0}$ \\
\hline
\end{tabular}


Berdasarkan jumlah gagal ginjal kronik yang mengalami anemia pada stadium $\mathrm{V}$ lebih banyak yaitu $95,31 \%$. Hal ini sesuai dengan penelitian Juni at al., (2015) dimama gagal ginjal kronik stadium $\mathrm{V}$ adalah tahap gagal ginjal akhir, pada stadium akhir gagal ginjal kronik kurang dari $90 \%$ masa nefron telah hancur, bahkan kurang dari jumlah tersebut, penderita menjadi oliguria (pengeluaran kemih kurang dari $500 \mathrm{ml} /$ hari karena kegagalan gromerulus). Pada stadium akhir gagal ginjal harus mendapatkan pengobatan dalam bentuk transpalantasi ginjal atau dialisis.

Tabel 5. Evaluasi efektivitas penggunaan obat antianemia

\begin{tabular}{cccc} 
Hemoglobin & Jumlah & $\begin{array}{c}\text { Rerata } \pm \\
\text { SD }\end{array}$ & p \\
\cline { 1 - 3 } Sebelum & \multirow{2}{*}{64} & $\begin{array}{c}7,8937 \pm \\
0,19984\end{array}$ & \\
\cline { 1 - 3 } Sesudah & \multirow{2}{*}{64} & $\begin{array}{c}9,4234 \pm \\
0,14047\end{array}$ & \\
\hline
\end{tabular}

*uji t berpasangan dengan taraf kepercayaan $95 \%$

Untuk melihat efektivitas antianemia dilakukan dengan membandingkan $\mathrm{Hb}$ sebelum dan sesudah terapi. Analisis dilakukan menggunakan uji $\mathrm{t}$ berpasangan dengan taraf kepercayaan 95\%. diketahui bahwa terdapat perbedaan yang bermakna antara hemoglobin sebelum dan sesudah terapi antianemia $(\mathrm{p}<0,05)$. Menurut penelitian Hidayah (2016), anemia pada gagal ginjal kronis sebagian besar ditandai dengan morfologi normositik normokrom. Anemia juga dapat disebabkan karena hemodialisis, kekurangan zat besi, asam folat, atau vitamin B12. Anemia pada penyakit gagal ginjal kronik sebagian besar disebabkan oleh defisiensi eryhropoesis stimulating factor (ESF). Hal ini yang ikut berperan terjadinya anemia adalah gangguan eritropoisis defisiensi besi, masa hidup eritrosit yang pendek akibat terjadinya hemolisis, defisiensi asam folat, pendarahan saluran cerna atau uterus, hemodialisis. Kadar hemoglobin merupakan salah satu indikator yang dapat digunakan untuk menunjukkan penurunan masa eritrosit (anemia). World Health Organization (2011) merekomendasikan kadar $\mathrm{Hb}$ yang masuk kriteria anemia adalah laki-laki dewasa $<13 \mathrm{~g} / \mathrm{dl}$, wanita dewasa tidak hamil $<12 \mathrm{~g} / \mathrm{dl}$, wanita hamil $<11$ $\mathrm{g} / \mathrm{dl}$. Dalam penelitian ini didapatkan kadar hemoglobin terendah adalah sebesar 4,5 g/dl dan tertinggi sebesar 13,2 $\mathrm{g} / \mathrm{dl}$. Pada penelitian ini beberapa subjek juga menerima transfusi darah.

Penggunaan asam folat memberikan pengaruh kepada pasien gagal ginjal kronik karena dapat meningkatkan kadar hemoglobin pasien dan dalam pembentukan sel darah merah, menstimulasi produk sel darah merah, sel darah putih dan platelet pada anemia megaloblastik Alvionita (2016). Eritropoetin bekerja pada suatu glikoprotein hormon yang akan terikat pada reseptor spesifik progenitor sel darah merah yang selanjutnya memberi sinyal merangsang proliferasi dan diferensasi. Produksi EPO akan meningkat pada keadaan anemia ataupun hipoksia jaringan (Ineck et al., 2008). Vitamin B12 merupakan nutrisi hematopoetik yang bekerja pada proses pembentukan sel darah merah (Bangbola, 2011; Capelli et al, 2019). Erythropoesis stimulating agent (ESA) bekerja dengan menstimulasi sumsum tulang untuk mempoduksi sel darah merah. Terapi ini bersifat individual dan digunakan dosis sekecil mungkin sudah cukup menurunkan kebutuhan transfusi darah (Masood, 2012; Ryu et al, 2018). Zat besi dibutuhkan untuk produksi sel darah merah baru. Zat besi harus disuplai menuju jaringan eritropoetik dalam jumlah cukup (Mikhail et al., 2012).

Terdapat 14 pasien yang menerima tranfusi darah selama menerima terapi antianemia. Penggunaan transfusi darah tentunya dapat mempengaruhi perubahan hemoglobin. Untuk itu dilakukan analisis nonparametric untuk mengetahui apakah transfusi darah juga mempengaruhi kadar hemoglobin. Data pengaruh tranfusi darah terhadap peningkatan hemoglobin dapat dilihat pada tabel 6 .

Tabel 6. Pengaruh transfusi darah terhadap peningkatan hemoglobin pasien GGK

\begin{tabular}{ccccc}
\hline \multirow{2}{*}{ Terapi } & \multicolumn{2}{c}{ Nilai } & & \\
& \multicolumn{2}{c}{ Hemoglobin } & Jumlah & p \\
\cline { 2 - 4 } & Naik & Turun & & \\
\hline Antianemia & 42 & 8 & 50 & \\
\cline { 1 - 4 } $\begin{array}{c}\text { Antianemia } \\
\text { transfusi } \\
\text { darah }\end{array}$ & 14 & 0 & 14 & $\left.0,183^{*}\right)$ \\
\cline { 1 - 4 } Jumlah & $\mathbf{5 6}$ & $\mathbf{8}$ & $\mathbf{6 4}$ & \\
\hline *Uji fisher dengan & & & & \\
\hline
\end{tabular}

Berdasarkan uji Fisher diketahui bahwa transfusi darah tidak berpengaruh terhadap kenaikan kadar hemoglobin ( $p>0,05)$. Dalam penelitian ini terdapat 14 subjek yang mendapatkan transfusi darah. Hal ini sesuai penelitian yang dilakukan oleh Erwin (2013) dimana jika pasien melakukan transfusi darah saat hemodialisis maka kadar hemoglobin akan naik drastis dan akan menyebabkan nilai kadar hemoglobin yang tidak akurat. Dalam penambahan darah atau transfusi darah pasti akan mengakibatkan suatu hasil kadar hemoglobin yang lebih tinggi. Manfaat transfusi 
darah adalah untuk menjaga ketersediaan oksigen, namun untuk pengobatan anemia pada gagal ginjal kronik sebaiknya dihindari untuk meminimalisir resiko terhadap kekebalan tubuh dengan adanya penambahan darah.

Transfusi darah pada pasien GGK sebaiknya dihindari karena memungkinkan trjadinya risiko seperti transfusion error, volume overload, errors, volume overload, hyperkalemia, citrate toxicity mengarah pada metabolic alkalosis dan hypocalcemia, hypothermia, coagulopathy, immunologically-mediated transfusion reactions, transfusion-related acute lung injury (TRALI), dan iron overload (KDIGO, 2012).

\section{SIMPULAN}

Dari hasil penelitian yang telah dilakukan, dapat disimpulkan bahwa penggunaan antianemia pada pasien gagal ginjal kronik sudah efektif dalam meningkatkan kadar hemoglobin.

\section{DAFTAR PUSTAKA}

Alvionita, Salma, 2016, Gagal ginjal kronik, Jakarta: Universitas Negeri Padang.

Atkinson, M.A. and Warady, B.A., 2018. Anemia in chronic kidney disease. Pediatric Nephrology, 33(2), pp.227-238.

Badan Penelitian dan Pengembangan Kesehatan Kementerian Kesehatan RI, 2013, Riset kesehatan dasar, Departement Kesehatan RI, 1-303. https://doi.org/1 Desember 2013.

Capelli, I., Cianciolo, G., Gasperoni, L., Zappulo, F., Tondolo, F., Cappuccilli, M. and La Manna, G., 2019. Folic acid and vitamin B12 administration in CKD, why not?. Nutrients, 11(2), p.383.

Cases, A., Egocheaga, M.I., Tranche, S., Pallarés, V., Ojeda, R., Górriz, J.L. and Portolés, J.M., 2018. Anemia of chronic kidney disease: Protocol of study, management and referral to Nephrology. Nefrología (English Edition), 38(1), pp.8-12.

Dinas Kesehatan Provinsi Bali, 2010, Profil kesehatan provinsi bali, Dinas Kesehatan Provinsi Bali.
Idaiani, S. 2011, Elderly people and women more risk to mental emotional disorders, Health Science Indonesia, 8-13.

Ineck, B., Mason, B. J., dan Lyons, W., 2008, Anemia, dalam Dipiro, J. T., Wells, B. G., Schwinghammer, T. L., dalam Dipiro, C. V., 7th Pharmacotherapy: a pathophysiologi approach, edisi 7, McGrawHill, New York.

Juni, P. J., Muchtar, N. R., Tjitrosantoso, H., dan Bodhi, W. 2015, gagal ginjal kronik yang menjalani perawatan di rsup prof. $d r . r . d$, Kandaou Manado, 4(3), 22-28.

Lubis, A. R., Siregar, J. H. 2011, Anemia pada penyakit ginjal kronik, 1-20.

McMurray, J.J., Parfrey, P.S., Adamson, J.W., Aljama, P., Berns, J.S., Bohlius, J., Drüeke, T.B., Finkelstein, F.O., Fishbane, S., Ganz, T. and MacDougall, I.C., 2012. Kidney disease: Improving global outcomes (KDIGO) anemia work group. KDIGO clinical practice guideline for anemia in chronic kidney disease. Kidney International Supplements, 2(4), pp.279-335

Morgan, G.E., Mikhail, M.S., Murray M.J., 2012, Crhonic pain management in clinical anesthesiology, edisi 5, Lange Medical Books/ McGraw-Hill.

Ryu, S.R., Park, S.K., Jung, J.Y., Kim, Y.H., Oh, Y.K., Yoo, T.H. and Sung, S., 2017. The prevalence and management of anemia in chronic kidney disease patients: Result from the korean cohort study for outcomes in patients with chronic kidney disease (knowckd). Journal of Korean medical science, 32(2), pp.249-256.

World Health Organization, 2011, Hemoglobin concetrations for the diagnosis of anemia and assesment of severity.

Xu, X., Qin, X., Li, Y., Sun, D., Wang, J., Liang, M., Wang, B., Huo, Y. and Hou, F.F., 2016. Efficacy of folic acid therapy on the progression of chronic kidney disease: the renal substudy of the China Stroke Primary Prevention Trial. JAMA internal medicine, 176(10), pp.1443-1450. 
Yuliati, dan Sri, 2017, Studi penggunaan asam folat pada pasien chronic kidney diease $(C K D)$, Malang: Universitas Muhamadiyah.
Zhang Qiu-Li, Rothebacter, D., 2008, Prevelence of chronic kidney desease in population based studies: Systematic Review, Germany: BMC Public Health. 